\title{
ELLJ
}

\section{Platform work in Europe: Lessons learned, legal developments and challenges ahead}

European Labour Law Journal 2022, Vol. 13(I) 4-29 (C) The Author(s) 2022 Article reuse guidelines: sagepub.com/journals-permissions DOI: $10.1177 / 20319525211062557$ journals.sagepub.com/home/ell

@SAGE

\section{Antonio Aloisi}

Assistant Professor and Marie Skłodowska-Curie Fellow, IE Law School, IE University, Madrid, Spain

\begin{abstract}
Several years since first emerging in Europe, platform work continues to represent a 'social dilemma' for workers, social partners, policymakers and society as a whole. As a result of intense litigation, analysis and reporting, much is known about the contractual and working conditions in this growing labour market segment. While the European Union (EU) institutions are considering adopting a new Directive based on Art. I53 TFEU, there are a number of significant top-down and bottom-up national cases worth discussing. Workers across Europe have been reclassified by many courts; some governments have taken regulatory initiatives to address the risk of precariousness and have implemented new comprehensive legal instruments to safeguard a level playing field for both workers and platforms. This article discusses how existing and new domestic and EU labour law provisions can improve the labour conditions of platform workers. Its overarching goal is to address possible policy gaps and the implications for EU social law by exploring the lessons that can be drawn from recent policies and legal developments.

Section two briefly touches upon the policymaking initiatives in France, Spain and Italy. Moreover, it presents and reviews the main outcomes of litigation at the domestic level, focusing on the pervasive role played by algorithmic management. After introducing the Pillar of Social Rights (EPSR), section three critically analyses two key achievements at the EU level: the Directive on transparent and predictable working conditions and the Recommendation on access to social protection for workers and the self-employed. Section four explores the elasticity of the triad of Directives that regulate atypical forms of employment (part-time, fixed-term and temporary agency work). It is argued that the narrow construction of the Directives' scope of application could represent an obstacle. However, an adaptive and purposive approach by the Court of Justice of the European Union (CJEU) could result in the classification of platform workers as falling within the scope of the social acquis in certain fields. Finally, section five concludes by providing concrete policy proposals focussed on cross-border issues, algorithmic transparency, the introduction of a presumption of employment status and collective bargaining.
\end{abstract}




\author{
Keywords \\ Gig economy, notion of worker, social acquis, platform work, atypical employment, European \\ Pillar of Social Rights
}

\title{
I. Introduction: EU labour Law at the beginning of the decade
}

Platform work is a new form of non-standard employment that emerged over the last decade. ${ }^{1}$ In this form of work, digital infrastructure facilitates the matching between the demand and supply of specific services and organises their performance utilising algorithmic management, customer reviews, internal ratings, incentives and automated decision-making systems. The scale, pace and volume of this evolving phenomenon has added new impetus to discussions in several fields of law, including public, antitrust, tax and IT law. In the face of the concomitant trends that are reshaping the labour market (globalisation, tertiarisation, outsourcing and flexibilisation, to name but a few), the manifold challenges the digital transformation poses have also reignited heated disputes about such crucial issues as (i) the suitability of traditional methods for defining the legal status of workers; (ii) the allegedly narrow scope of the application of labour regulations; and (iii) whether existing labour and social security paradigms can adapt to changes in the labour market.

The overarching theme of this article is to address possible policy gaps and further implications for European Union (EU) labour law by exploring the lessons that can be drawn from recent policies and judicial developments. This study deliberately takes some central issues for granted for two main reasons. On the one hand, a selection of cases is necessary due to space constraints. On the other, numerous studies have refocused the crux of the discussion, have resolved some points of controversy and moved the debate forward. As a result, ongoing research can now focus on a pressing goal, namely, assessing the regulatory suitability of existing social institutions to provide prompt, realistic and effective solutions for all actors involved in the platform economy. Before doing so, a summary of several important aspects on which a consensus has emerged will allow us to prepare the grounds for the legal analysis.

Despite multiple efforts to draft a comprehensive and accurate definition, there is no clear consensus on the definition of 'platform work' due to the extreme heterogeneity of the phenomenon. When studying the implications of casual work patterns made possible by tools that are permanently connected, a number of variables need to be considered (location, flexibility, management models, payment systems, etc.), thus leading to a situation where variance far exceeds shared characteristics. Consequently, from a policy perspective, one-size-fits-all measures may prove ineffective, if not detrimental. However, the overexposure of common issues is convenient for analytical and regulatory purposes, as responses need to be broad enough to be applicable to a variety of concrete situations.

Nonetheless, two major categories of platform work can be distinguished: (i) activities performed remotely and (ii) those performed on location. ${ }^{2}$ These two categories have been referred

1. Uma Rani and others, World Employment and Social Outlook: The Role of Digital Labour Platforms in Transforming the World of Work (International Labour Organisation 2021); Willem Pieter De Groen and others, Employment and Working Conditions of Selected Types of Platform Work (Publications Office of the European Union 2018); Eurofound, New Forms of Employment (Publications Office of the European Union 2015).

2. Valerio De Stefano, 'The Rise of the Just-in-Time Workforce: On-Demand Work, Crowdwork, and Labor Protection in the Gig-Economy' (2015) 37 Comp. Lab. L. \& Pol'y J. 471; Miriam A Cherry, 'Beyond Misclassification: The Digital Transformation of Work' (2015) 37 Comp. Lab. L. \& Pol'y J. 577. 
to as 'crowdwork' and 'work on demand via a platform', respectively. Scholars have paid a great deal of attention to the latter. Consequently, there is scant knowledge about EU-based workers who resort to digital platforms to perform tasks online, without any face-to-face interaction. ${ }^{3}$ This approach, with a few exceptions, is reflected in the regulatory measures adopted, in case law and in most of the social partners' initiatives. There are several explanations for this, the leading reason being that workers operating in specific locations have joined forces to exert pressure on trade unions and legislators. Yet 'crowdwork' features critical elements that should not be underestimated, although it might be difficult to determine the most appropriate level of intervention. ${ }^{4}$

The Covid-19 pandemic has magnified the insecurity of all non-standard workers, and its impact has been disproportionate on platform workers who have borne the brunt of the socioeconomic crisis. ${ }^{5}$ The pandemic has also exacerbated some of the vulnerabilities associated with this form of work. On-location workers felt unprotected, as they were constantly exposed to the risk of contagion or forced to choose between economic hardship due to the absence of financial assistance schemes or the risk of infection to the detriment of their families and colleagues. Several reports detail a drop in unsteady incomes due to reductions in demand or an inability to work for various reasons. ${ }^{6}$ Many workers faced a reduction in their already irregular working hours, yet the transaction volumes of many services offered by online platforms increased. Most measures to protect workers ranging from contactless delivery and payment to the distribution of personal protective equipment were merely preventative in nature. $^{7}$

The most reliable estimates suggest that employment in platform work accounts for around 1\% to $3 \%$ of total employment. ${ }^{8}$ Approximately $1.5 \%$ of the working-age population (16-74 years) state that platform work is their main occupation; ${ }^{9}$ it is estimated that $11 \%$ of adults have earned income from platform work at some point in time. ${ }^{10}$ Regardless of the dimension of this phenomenon, ${ }^{11}$ which is relatively complex to quantify from a statistical perspective, it is undeniable that many workers face the looming consequences of the scarce efficacy of labour protection resulting from a combination of deliberate attempts to circumvent employment legislation with the aim of

3. Janine Berg and others, 'Digital labour platforms and the future of work, Towards Decent Work in the Online World' (International Labour Organisation 2018).

4. ILO, 'Work for a Brighter Future, Report of the Global Commission on the Future of Work, 2019', available at https:// bit.ly/3gskNcH; Annarosa Pesole and others, Platform Workers in Europe (Publications Office of the European Union 2018).

5. Eurofound, COVID-19: Implications for Employment and Working Life, COVID-19 Series (Publications Office of the European Union 2021).

6. Eurofound, Back to the Future: Policy Pointers from Platform Work Scenarios (Publications Office of the European Union 2020).

7. Stefano Scarpetta and others, What Have Platforms Done to Protect Workers During the Coronavirus (COVID 19) Crisis? (OECD 2020), available at https://bit.ly/33f9A9D. Marguerita Lane, 'Regulating Platform Work in the Digital Age' in Going Digital Toolkit Policy Note (No. 1, OECD 2020), available at https://bit.ly/311EXL9.

8. CEPS, EFTHEIA and HIVA-KU Leuven, 'Study to Gather Evidence on the Working Conditions of Platform Workers. VT/2018/032 Final Report' (2020). See also Nestor M. Davidson and others, The Cambridge Handbook of the Law of the Sharing Economy (Cambridge University Press 2018).

9. OECD, 'Gig Economy Platforms: Boon or Bane?' in Economics Department Working Paper 1150 (OECD 2019); Sara Riso, Mapping the Contours of the Platform Economy (Working Paper, Eurofound 2019).

10. Cesira Urzì Brancati and others, Digital Labour Platforms in Europe: Numbers, Profiles, and Employment Status of Platform Workers (No. JRC117330, Joint Research Centre 2019).

11. Agnieszka Piasna, 'Counting Gigs: How Can We Measure the Scale of Online Platform Work?' (2020) ETUI Research Paper. 
cost-cutting and the ambiguity of certain regulations and laws. This vividly demonstrates that further emphasis must be placed on enhancing the social dimension by making quality jobs an urgent priority for all parties involved, not to mention the need to strengthen the enforcement of widely recognised rules and to ensure the observation of basic provisions. This also raises questions about the willingness of EU institutions and national governments to deliver a stronger social agenda. As will be argued in this article, after a long period of disengagement, positive signs are emerging in Europe's multi-level legal order, but a lot more work needs to be done. ${ }^{12}$

This article is organised as follows. Aside from discussing the key lessons gleaned from previous studies on platform work, section two briefly touches upon the trends and initiatives in policymaking in Spain, Italy and France. Moreover, it presents and reviews the main outcomes of litigation at the domestic level in a selection of EU countries and the UK, focusing on the role played by algorithmic governance. After introducing the Pillar of Social Rights (EPSR), section three critically analyses two key achievements at the EU level: the Directive on transparent and predictable working conditions and the Recommendation on access to social protection for workers and the self-employed. Section four assesses the elasticity of the triad of Directives regulating atypical employment. It is argued that the narrow construction of the Directives' scope of application represents an obstacle. An adaptive and purposive approach of the Court of Justice of the European Union (CJEU) could, however, result in the classification of platform workers as falling within the scope of the social acquis, at least in some fields. Finally, section five concludes by providing a distillation of concrete policy proposals focused on cross-border issues, algorithmic transparency, the introduction of a presumption of employment status and collective bargaining.

\section{Policy and Legal Developments Across the European Union}

There has been intense activism at both the EU and national levels in response to the advent of platform work and its regulation. In general, local initiatives specifically tailored to this form of work are still sporadic. At the same time, we are witnessing a flood of litigation before domestic courts on the legal status of platform workers, generating widespread public interest.

\section{A. National Trends and Initiatives in Policymaking}

Considering the pragmatic nature of this article, it only examines three legislative solutions in detail. In Spain, Italy and France, where a binary distinction between employment and selfemployment still applies (although the Italian and Spanish frameworks have introduced intermediate solutions such as 'quasi-subordinate' work and 'economically dependent self-employment'), policymakers have implemented diverse policy options. In Spain, a specific, rebuttable presumption of the employment status was introduced in 2021, after a six-month process of tripartite social dialogue (concertación social). Today, delivery couriers fall within the scope of statutory labour protection. Similarly, in 2019 and 2015, the Italian government expanded the full coverage of mandatory employment protection for self-employed workers who are not genuinely autonomous (i.e. when work performance is organised by the principal). Conversely, the 2016 French law

12. Sacha Garben, 'The European Pillar of Social Rights: An Assessment of Its Meaning and Significance' (2019) 21 Cambridge Yearbook of European Legal Studies 101; Silvia Rainone and Antonio Aloisi, Time to Deliver? Assessing the Action Plan on the European Pillar of Social Rights (ETUI Policy Brief 2021). 
refrained from taking a definitive stance on workers' legal status by defining a special regime: platforms must respect a set of obligations relating to insurance and training for 'dependent' selfemployed platform workers. In the same vein, the 2019 French reform encourages the adoption of codes of practice that define the rights and obligations of platform workers.

In May 2021, Spain passed a new law known as the Ley Rider, ${ }^{13}$ clarifying the status of delivery riders and introducing the right to be informed about the logic of algorithms that govern the work relationship. As a result, all personal activities consisting of the delivery and distribution of any consumer product or merchandise in exchange for remuneration and under the direct, indirect or implicit direction of a company using algorithms or platforms fall within the scope of statutory employment law. This presumption of employment has been established by amending or better clarifying the current Workers' Statute's scope. Unions and employer representatives agreed on the text based on a social dialogue process. ${ }^{14}$ The Ley Rider gave delivery companies three months to adapt to the new model. The reasoning behind a major ruling issued by the Supreme Court undoubtedly contributed to shaping this provision, which is primarily aimed at fighting bogus self-employment. It must be noted, however, that the scope of the new law is very narrow; many workers who perform on-location services, not to mention crowdworkers, could remain excluded from the social protection attached to employment status. At the same time, it is not clear whether platforms will comply with the law or resort to alternative outsourcing strategies, for instance, by signing contracts with external staffing companies or temporary work agencies.

Moreover, according to the new law, workers' legal representatives shall have the right to be informed about AI (artificial intelligence) or algorithm-fuelled metrics, rules and instructions that result in decisions on working conditions, access and retention of work, including profiling. The text resembles an expansive transposition of Articles 13 and 14 on information to be provided, Article 15 on the right of access and Article 22 GDPR on automated individual decision-making, including profiling. The law has been welcomed as 'ambitious at first sight' for its novelty. ${ }^{15}$ Its personal ambit of application includes all workers who are in a relationship with a platform, regardless of their contract. As for content, while providing workers with the possibility to learn more about the parameters, rules and instructions of algorithms or AI systems, the law does not introduce additional rights on the co-determination of such metrics. This collective right to information may contribute to making algorithms more transparent, but systems of objection and redress are lagging. By operating in conjunction with the GDPR, however, the new provision could pave the way to a modern understanding of algorithmic accountability, combining national efforts and traditions on workplace monitoring with the general EU framework on data protection.

The new Italian law approved in 2019 is among the very few legislative initiatives directly addressing platform workers. In November 2019, Legislative Decree No. 101/2019 was amended and became Law No. 128/2019. ${ }^{16}$ The new law comprises two main schemes. The first

13. Jefatura del Estado, 'Real Decreto-ley $9 / 2021$, de 11 de mayo, por el que se modifica el texto refundido de la Ley del Estatuto de los Trabajadores, aprobado por el Real Decreto Legislativo 2/2015, de 23 de octubre, para garantizar los derechos laborales de las personas dedicadas al reparto en el ámbito de plataformas digitales' (2021) 113 BOE 56733.

14. Ane Aranguiz, 'Spain's Platform Workers Win Algorithm Transparency' (2021) Social Europe, available at https:// socialeurope.eu/spains-platform-workers-win-algorithm-transparency.

15. Carmen Villarroel Luque, 'Workers vs Algorithms: What Can the New Spanish Provision on Artificial Intelligence and Employment Achieve?' (2021) VerfBlog, available at https://verfassungsblog.de/workers-vs-ai/.

16. Law No. 128/2019 amending Decree 101/2019 on urgent measures for the protection of work. 
covers workers whose personal performance is organised by the client 'also by means of digital platforms'. In contrast, the second scheme defines a set of labour protection measures for 'selfemployed couriers delivering goods by means of two-wheeler vehicles in urban areas'.

The first section amended a rule introduced by the 2015 Jobs Act reform package. According to the new wording of Article 2 of Legislative Decree No. 81/2015, employment and labour legislation apply to 'personal work organised by the other party' (etero-organizzato, a subset of arrangements, whereby the client organises any performance-related aspects). The original version expressly referred to location and time allocation as key factors. The new personal scope of employment protection has been expanded to include all 'organisationally' dependent workers, regardless of their status, albeit indirectly (i.e. without modifying the relevant notions of the Civil Code). The rule has applied since 2019 also when the client's unilateral intervention is exercised through a digital platform. Collective agreements may include opting out of this regime by designing a contractual and economic model that replaces the legislative scheme. The provision has made it easier to prove the organisational power exercised by the principal. Its tangible remedial effect for dependent self-employed workers who have unreasonably been left outside the ambit of protection has been confirmed by a judgment issued by the Supreme Court in January 2020, offering a farreaching interpretation of the 2015 'Jobs Act' rules. Anyone deemed etero-organizzato is entitled to labour and employment protection unless a collective agreement specifically states otherwise. ${ }^{17}$

The second section only covers 'self-employed riders', namely, those who do not fall within the scope of the first section. The section lays down a mandatory written form for contracts. The social partners were expected to reach an agreement detailing remuneration levels within one year of the date of entry into force of the law. In the absence of such collectively negotiated schemes, wages are to be defined in accordance with the minimum standards established in national collective bargaining agreements for sectors similar to that of the relevant business, while per-drop payments are prohibited. In addition, an indemnity for work performed by riders during night shifts, public holidays or in adverse weather conditions, as well as mandatory insurance against work accidents and occupational diseases, have been established. The law includes provisions on data protection and anti-discrimination. ${ }^{18}$

In 2016, the French Parliament adopted the El Khomri law. This initiative specifically targets self-employed platform workers (travailleur indépendant) who use one or more digital platforms to provide personal services. ${ }^{19}$ Only economically and technically dependent workers engaged by the platforms, which determine the properties and set the service prices, fall within the law's scope of application. Article 60 of the law confers specific rights on this group of workers, including protection against accidents at work, the right to vocational training and collective rights (right to strike). Although this intervention should not be considered a legal presumption, the indirect result

17. Antonio Aloisi, 'A Fascinating Chapter in the 'Gig' Saga. How to Deliver Decent Work to Platform Workers in Italy?', Mutual Learning Programme, DG Employment, Social Affairs and Inclusion (European Commission 2020).

18. In September 2020, the Food Delivery Platform Association and a small trade union signed an agreement aimed at eluding the application of the statutory provisions set forth in the two reforms. The agreement includes health and safety protection, training opportunities and collective rights and specifies that riders are self-employed workers. Self-organised collectives, long-established unions and the Italian Ministry of Labour challenged the text. A new 'Protocollo Riders' was signed in November 2020 by major unions and employer organisations in the transport and logistics sector. Riders are classified as employees and have access to protection afforded to standard workers in the relevant sector.

19. Law 2016-1088 (8/8/2016) on labour, the modernisation of social dialogue and securing of professional careers. See new Art. L. 7341-1 and Art. L. 7342-1 of the French Labour Code. 
was the creation of a category of autonomous workers eligible for limited protection. According to Daugareilh et al. ${ }^{20}$ the El Khomri Act can be regarded as 'an attempt to create a third status without actually naming it'. The prevention of abuse and reduction in litigation over the proper classification of workers can be considered a side effect of the creation of such an intermediate category of 'vulnerable self-employed platform workers'. In 2019, the French Parliament adopted a new law (Orientation des mobilités), providing for the right of VTC (private hire vehicle) drivers, delivery couriers as well as other platform workers to refuse certain orders, to disconnect from the app and to be informed about the price before taking a call. ${ }^{21}$ The law furthermore allows platform operators to draft a social responsibility charter. The attempt to prevent misclassification claims, however, was deemed unconstitutional by the French Constitutional Court. In 2021, the law is set to recognise platform workers' delegates for consultations with platforms on voluntary codes of practice and negotiations at the sectoral level. ${ }^{22}$

These national cases demonstrate that legal classification is of utmost importance, and not only for platform workers, as it represents an essential gateway to meaningful protection. Certain legal options may overcome the classification dilemma by broadening the scope of certain protective measures to include vulnerable self-employed workers, as the Italian case presented above shows. However, it is worth noting that the adoption of third categories-construed around criteria that are less stringent than those underpinning the definition of employment ${ }^{23}$ can lead to widespread arbitrage, favoured by the existence of inexpensive alternatives to employment. $^{24}$

\section{B. Gaming the 'Gate': national case law on platform workers}

Platform work is an ideal testbed for analysing the suitability of the 'binary divide' between employment and self-employment found in many legal orders. Though not specific to platform work only, the salient debate echoes long-lasting discussions on whether a dualistic logic (allowing for only a few exceptions in some countries) can provide adequate responses for a world of work in which unprecedented organisational arrangements are on the rise.

Platforms engage with providers who are pre-emptively and predominantly classified as selfemployed workers. This notwithstanding, many of them exert some degree of managerial prerogative, albeit in a sophisticated and misleading manner, while avoiding the obligations and costs associated with direct employment. Workers are paid by the task rather than by the hour (while search and waiting times are usually not compensated). They are constantly subject to performance appraisal techniques. In addition to casting doubts on the sustainability of a competitive edge resulting from cost-cutting practices, not to mention the issue of unfair competition against other operators in the same sector, this model deprives workers of labour-related protection, corollary social

20. Isabelle Daugareilh and others (eds.), The Platform Economy and Social Law: Key Issues in Comparative Perspective (ETUI 2019).

21. Law 2019-1428 (24/12/2019) on mobility orientation (LOM). See also Conseil constitutionnel, Décision $n^{\circ} 2019-794$ DC 20/12/2019.

22. Barbara Palli, Regulation of Platform Work in France: From Voluntary Charters to Sector-Wide Collective agreements?, Mutual Learning Programme, DG Employment, Social Affairs and Inclusion (European Commission 2020).

23. Jason Moyer-Lee and Nicola Contouris, 'Taken for a Ride: Litigating the Digital Platform Model' in International Lawyers Assisting Workers Network (ILAW 2021).

24. Mariam A. Cherry and Antonio Aloisi, 'Dependent Contractors in the Gig Economy: A Comparative Approach' (2016) 66 American University Law Review 635. 
benefits and collective rights. ${ }^{25}$ The system does not contain any entitlements, such as overtime, paid holiday leave, maternity leave, sickness payments, compensation for wrongful termination and statutory (or collectively negotiated) minimum wages. In addition, workers face legal and practical obstacles in exercising fundamental rights, such as freedom of association, collective bargaining or protection against discrimination. In some cases, these business models may have fuelled a spectacular rise in false self-employment. ${ }^{26}$

Although commended as being 'essential' during the first phases of the lockdown measures implemented to mitigate the risk of contagion, platform workers fell through the cracks of emergency measures with limited access to unemployment benefits, health insurance and sick leave, given their discontinuous and irregular engagements. ${ }^{27}$ Specifically, many platforms avoided taking decisive action to minimise the risk of misclassification lawsuits. In turn, workers have faced the paradoxical consequences of their legal status, as platforms have issued rigorous instructions on good hygiene practices yet have transferred all responsibilities to workers.

Platforms are embroiled in several lawsuits on the appropriate classification of workers. This section provides an overview of the principal lines of reasoning developed by courts in several EU countries. It would admittedly be imprudent to generalise specific judgments, as they are factdependent. An 'all-or-nothing' approach is found in many jurisdictions, with notable exceptions. While the preliminary judicial results were mixed, erratic or even utterly contradictory, the fight over the appropriate classification of gig workers is moving into a new phase of nearly unanimous recognition of the existence of an employment relationship. However, platforms often respond by tweaking the terms and conditions to thwart the rulings' significance.

When analysing what is at stake in pending litigation involving the classification of workers, we find that the issue has been dealt with in two conflicting ways across Europe. The subordination 'test' is carried out by weighing different factors, the issue of 'control' being a prominent metacriterion. Despite the sensitivity of multifactorial tests to factual variations, the resolution of legal disputes brought before higher courts quite often leans towards recognition of an employment relationship. These disputes have resulted in the rejection of platform workers' claims in a few cases, placing them outside the scope of protection because of their supposed freedom to decide if and when they turn on the app and carry out a task or project. ${ }^{28}$ This argument is far from convincing, as it does not consider the capacities of digital tools when it comes to organising, monitoring and sanctioning workers in stringent yet subtle ways. To classify the nature of the activity, judges must assess the role of apps that design constrained conditions of possibilities, rather than focusing on the formal obligation to provide work and perform an assignment. ${ }^{29}$ This peculiar choice architecture results in workers' subjection to personal or material directives and to the supervision and disciplinary power exerted by platforms. ${ }^{30}$

25. Valerio De Stefano and Antonio Aloisi, European Legal Framework for Digital Labour Platforms (European Commission 2018).

26. Antonio Aloisi, 'Hierarchies without firms? Vertical disintegration, outsourcing and the nature of the platform' (E-book "Quaderni 8th Giorgio Rota Best Paper Award" 2020).

27. The Fairwork Project, 'The Gig Economy and Covid-19: Looking Ahead' (2020), available at https://bit.ly/2JHSMln.

28. Valerio De Stefano, 'Platform Work and Labour Protection. Flexibility Is Not Enough' Regulating for Globalization (2018), available at https://bit.ly/339UjXx.

29. Benjamin Sachs, 'Enough with the Flexibility Trope' in On Labor (2018), available at https://onlabor.org/enough-withthe-flexibility-trope/.

30. Karen Yeung, 'Why Worry About Decision-Making by Machine?' in Algorithmic Regulation (Oxford University Press 2019) 21. 
In September 2020, the Spanish Supreme Court held that Glovo food delivery riders were employees since the platform dictated working conditions; the platform unilaterally determined the rates, and the performance of such work was integrated into the business of the firm, which was also the owner of the digital infrastructure, a critical factor of production. ${ }^{31}$ In November 2019, the Tribunal Superior de Justicia de Madrid held that the relationship between the platform Glovo and the riders was framed within the context of an employment relationship. ${ }^{32}$ In June 2018, two rulings issued by the Valencia Juzgado de lo Social stated that Deliveroo riders were employees because they were subject to the tight control of the platform, which monitored their performance and determined the terms and conditions of the work, including the prices of the service. ${ }^{33}$ A similar argument was made in a case decided by the Barcelona Juzgado de lo Social. ${ }^{34}$

In Italy, the Supreme Court applied the bulk of employment protection laws to a group of Foodora riders in January 2020, inappropriately classified as self-employed 'collaborators'. By analysing the effective modalities of work performance, the Court stated that these were organised by the client, triggering the enforcement of the 2015 law provision. ${ }^{35}$ In November 2020, the Palermo Tribunal reinstated a Glovo rider and reclassified him as a full-time, permanent employee, to be paid according to the applicable sectoral collective bargaining (trade), since his autonomy was merely nominal. ${ }^{36}$ Previously, the Milan Tribunal had decided that a Glovo rider was a self-employed person as he had the freedom to decide if and when to be available for the company. ${ }^{37}$

In 2020, the French Cour de Cassation reclassified the contractual relationship between Uber and a driver as an employment contract. ${ }^{38}$ The Court held that the driver could not be classified as a commercial partner with independent access to the market or clients, ${ }^{39}$ and also pointed out that despite the workers' freedom to choose their own work schedule, the platform had the power to set prices, organise the performance of work, monitor its execution, and impose sanctions on drivers. In 2018, the same Court reviewed the Take Eat Easy ruling and concluded that the combination of real-time geo-tracking applications and disciplinary sanctions amounted to a degree of direction and control that warranted the establishment of employment status. ${ }^{40}$

British courts reached an opposite decision in two cases involving drivers and couriers. The first case, dating back to 2016, placed Uber drivers in an intermediate category of 'worker' within the meaning of the Employment Rights Act, entitled to minimum wage, working time protection and freedom of association (including a right to strike and to union recognition for collective bargaining purposes). ${ }^{41}$ The Employment Appeal Tribunal argued that the platform

31. Tribunal Supremo, 'Sala de lo Social' Case 4746/2019 (2020).

32. Tribunal Superior de Justicia de Madrid, 'Sección nº 01 de lo Social' Case 1155/2019 (2019).

33. Juzgado de lo Social $n^{\circ} 5$ de Valencia, Case 197/2019 (2019); Juzgado de lo Social nº 6 de Valencia, Case 244/2018 (2018).

34. Juzgado de lo Social $n^{\circ} 11$ de Barcelona, Case 213/2018 (2018).

35. Corte di Cassazione, Sez. Lavoro, Sentenza 1663/2020 (20200. See Silvia Borelli, 'Fitting the Panoply in a Binary Perspective. The Italian Platform Workers in the European Union' (2020) 41 Comp Lab L \& Pol'y J 365.

36. Tribunale di Palermo, Sentenza 3570/2020 (2020). See Antonio Aloisi, 'Demystifying Flexibility, Exposing the Algorithmic Boss: A Note on the First Italian Case Cassifying a (Food-Delivery) Platform Worker as an Employee' (2021) Comp Lab L \& Pol'y J.

37. Tribunale di Milano, Sentenza 1853/2018 (2018).

38. Cour de Cassation, Chambre Sociale, Arrêt 374 (19-13.316, 2020).

39. D. Georgiou, 'Business Risk-Assumption' as a Criterion for the Determination of EU Employment Status: A Critical Evaluation' (2021) Industr Law J.

40. Cour de Cassation, Chambre Sociale, Arrêt 1737 (17-20.079, 2018).

41. Employment Tribunal, Y. Aslam, J. Farrar \& Others v Uber, Case 2202551/2015 (2016). 
exercised significant control over how drivers performed their work. ${ }^{42}$ In 2021 , dismissing an appeal by Uber, the UK Supreme Court unanimously classified Uber drivers as 'workers' for the purpose of national minimum wage and working time regulations, not as genuinely self-employed persons given their merely notional autonomy. ${ }^{43}$ The Court also stated that a purposive approach must be adopted when defining the ambit of application of a particular statute, which extends beyond the written terms of the contract. By contrast, in 2018, the Central Arbitration Committee and the High Court denied food delivery workers statutory collective labour rights by virtue of a (purposely introduced and hardly practicable) substitution clause, defeating the criterion of personal work. ${ }^{44}$

In Germany, employee status was denied in two separate cases. ${ }^{45}$ However, in December 2020, the German Federal Labour Court (BAG) stated that on-location platform workers who carry out microtasks can be classified as parties to an employment relationship. ${ }^{46}$ According to the BAG, an employment relationship exists when one party controls the performance of work, leaving no discretion to the worker in terms of the activity's place, time and content. Despite the lack of a contractual obligation to accept offers from the platform, workers were 'personally dependent' on the binding instructions issued by the platform within the organisation based on incentives constraining the workers' autonomy. The 'far-reaching' decision could pave the way to a broader notion of employment. ${ }^{47}$ In Brussels, a Belgian court in 2019 stated that Uber drivers were self-employed workers, ${ }^{48}$ as they were free to decide when, where and how long they wanted to work.

This selection of rulings highlights the difficulties of relying on complaint-based case law to shape consistent outcomes for platform workers. However, by assessing the long catalogue of manifold judicial parameters used by the local tribunals and high courts in similar recent judgments in Spain, Italy, France and the UK, we detect the emergence of a consistent set of patterns that are defining a legal blueprint on how to address a misclassification claim. In this network of inspirations, the exposure of the 'autonomous worker' fiction, confuting the contractual classification, also resonates with the Court of Justice of the European Union's (CJEU) case law. ${ }^{49}$ This use of the comparative method, particularly notable in the 2020 Spanish ruling, reinforces the ties of a pan-European 'community of courts' ${ }^{50}$ It starkly demonstrates the rise of a supranational public sphere where tribunals cooperate in a special adjudication system to establish a promising dialogue

42. Employment Appeal Tribunal, Uber v Y. Aslam, J. Farrar \& Others, Case A2/2017/3467 (2018).

43. The UK Supreme Court, B. V. Uber and others v Aslam and others, Case [2021] UKSC 5. See Diane Coyle and others, 'Uber and Beyond: Policy Implications for the UK' (The Productivity Institute 2021); Alan Bogg, 'For Whom the Bell Tolls: "Contract" in the Gig Economy' (Oxford Human Rights Hub 2021), available at https://bit.ly/2TiZORP.

44. Central Arbitration Committee, 'Independent Workers' Union of Great Britain v RooFoods Ltd t/a Deliveroo', Case CO/ 810/2018 (2018).

45. Lag München, Case 8 Sa 146/19 (2019). LAG Hessen, Case 10 Ta 350/18 (2019).

46. Bundesarbeitsgericht, Case 9 AZR 102/20 (2020).

47. Martin Risak-Gruber, 'Platform Without Working? Protection Towards Strategies Legal European the in Conditions Working Good Economy Platform' (Israel Public Policy Institute 2021).

48. Tribunal de l'Entreprise francophone de Bruxelles, Case 311 (2018).

49. Case C-256/01, Debra Allonby v Accrington \& Rossendale College [2004] ECLI:EU:C:2004:18; Case C 413/13, FNV Kunsten Informatie en Media v Staat der Nederlanden [2014] ECLI:EU:C:2014:2411.

50. C. Kilpatrick, 'Community or Communities of Courts in European Integration' (1998) 4(2) Eur Law J 121; Bruno De Witte and others (eds.), National Courts and EU Law: New Issues, Theories and Methods (2015). 
both horizontally (among the different Member States) and vertically (between lower and higher courts within a country and-importantly-on the international front). ${ }^{51}$

In this 'rich exchange of messages', a new social dimension is developing that transcends domestic legal systems. ${ }^{52}$ Reading the fine print of these intriguing jurisprudential developments, it becomes apparent that such a conversational relationship between courts is also consolidating a gradual, bottom-up cohesion in a context of dynamic cross-fertilisation. Foreign courts pay attention to what courts in other jurisdictions have decided. This comes as no surprise: several cases involve workers hired by the same multinational companies, applying comparable conditions and replicating the same business organisation. Space limitation here precludes extensive exploration of this exchange, which is a matter for future research. However, this 'rather complex interpenetration of the legal systems' is likely to produce a new dimension of pluralist legal thought. ${ }^{53}$ It remains to be seen how the circulation will unfold case by case and whether it will lead to common institutional developments facilitated by the EPSR's momentum. Very interesting times are ahead for those longing for a more socially oriented Europe.

\section{Building the European Pillar of Social Rights Brick by Brick}

In January 2017, the European Parliament adopted a resolution on the European Pillar of Social Rights, in which it advocates 'for work intermediated by digital platforms [...], a clear distinction-for the purpose of EU law and without prejudice to national law-between those genuinely self-employed and those in an employment relationship, taking into account ILO Recommendation No. 198, according to which the fulfilment of several indicators is sufficient to determine an employment relationship'. ${ }^{54}$ Later that same year, the Parliament adopted a resolution on a European Agenda for the collaborative economy, ${ }^{55}$ calling on the Commission to examine how far existing Union rules are applicable to the digital labour market and ensure adequate implementation and enforcement'.

The EPSR ${ }^{56}$ was proclaimed at the Social Summit for Fair Jobs and Growth in Gothenburg, Sweden, on 17 November 2017. Commentators welcomed this vigorous expression of political commitment as a timely and essential initiative against the rise of anti-EU sentiment. Despite its more exhortatory than mandatory nature, the Pillar marks a new promising step in strengthening

51. See C-434/15 Asociación Profesional Elite Taxi v Uber Systems Spain [2014] ECLI:EU:C:2017:981. The CJEU stated that ' $[. .$.$] Uber determines at least the maximum fare by means of the eponymous application, [...] the company receives$ that amount from the client before paying part of it to the non-professional driver of the vehicle, and [...] it exercises a certain control over the quality of the vehicles, the drivers and their conduct, which can, in some circumstances, result in their exclusion' (para. 39).

52. Something similar to what Professor Sciarra described as regards the impact of preliminary rulings is occurring in the field of social protection of platform workers. S. Sciarra (ed.), 'Integration Through Courts: Article 177 as a Pre-Federal Device' (2001) Lab Law Courts ('national judges scattered in all Member States [...] are constantly listening to the dialogue and may even tune into it and speak their own words').

53. David Edward, 'National Courts-The Powerhouse of Community Law' (2003) 5 CYELS 1.

54. European Parliament resolution of 19 January 2017 on a European Pillar of Social Rights (2016/2095(INI)). See Antonio Aloisi, 'The Role of European Institutions in Promoting Decent Work in the 'Collaborative Economy', in M. Bruglieri (ed.), Multidisciplinary Design of Sharing Services (Springer International Publishing 2018).

55. European Parliament resolution of 15 June 2017 on a European Agenda for the collaborative economy (2017/ 2003(INI)). See also Communication of 2 June 2016, A European agenda for the collaborative economy ( $\operatorname{SWD}(2016) 184)$ (a central section is devoted to 'labour law and worker classification').

56. Interinstitutional Proclamation on the European Pillar of Social Rights (2017/C 428/09). 
the EU social dimension. Indeed, the EPSR provides guidance on how EU institutions should understand social rights and principles.

The current Commission is expected to continue delivering on this, even more so after President von der Leyen asked the Commissioner for Jobs and Social Rights 'to develop an action plan to implement the Pillar'. ${ }^{57}$ In January 2020, the Commission presented a communication that included a proposal to organise a 'Platform Work Summit' to discuss priority issues and solutions. ${ }^{58}$ The Summit did not occur due to the Covid-19 crisis, but a wide range of consultations was held with stakeholders in autumn 2020. In October, the Commission adopted its 2021 Work Programme, which includes a legislative proposal (based on Art. 153 TFEU) to improve the working conditions of platform workers and ensure adequate social protection. ${ }^{59}$ The new 2021 'European Pillar of Social Rights Action Plan' includes two important legislative initiatives, notably on collective bargaining for autonomous workers who are in a vulnerable position, and on the working conditions of platform workers. In February 2021, the Commission began consultations with the social partners in accordance with Article 154(2) of the Treaty on the Functioning of the European Union (TFEU), requesting their opinion on the possible direction of EU action to improve the working conditions of those working through digital labour platforms active in the EU. The second-stage consultation was launched in June 2021, requesting European social partners to submit their views on potential instruments for EU action. A bold initiative was presented at the end of 2021, which could change the fate of platform workers for the better. ${ }^{60}$ All eyes are now on implementation.

\section{A. The New Directive on Transparent and Predictable Working Conditions: One small step forward}

A direct follow-up to the EPSR is the new Directive (EU) 2019/1152 on transparent and predictable working conditions. Even though it is too early to evaluate the efficacy of the new measures laid down in the Directive, a preliminary assessment can be made. The most important rights platform workers could benefit from include: (i) limitations to the use and duration of casual contracts, (ii) ban on unnecessary exclusivity clauses and (iii) possible definition of a rebuttable presumption of the existence of an employment contract or relationship with a guaranteed number of paid hours based on the hours worked in a preceding reference period. At the same time, the enforcement of rules on the 'timely provision of information about the terms and conditions of collaboration, including on work allocation, organisation and evaluation' will benefit platform workers. ${ }^{61}$ Another important aspect is that on account of the EPSR, the new Directive also serves as a tool to manifest and advance the EU social acquis, provided that Member States are keen to adequately transpose it to achieve its ambitious goals. The deadline to transpose it is August 2022.

57. Ursula von der Leyen, Mission letter to Nicolas Schmit, Commissioner-designate for Jobs (2019).

58. Communication of 14 January 2020, ‘A Strong Social Europe for Just Transitions' (COM(2020) 14). A Proposal for a Directive on Adequate Minimum Wages in the European Union (COM(2020) 682) was released based on Article 153 TFEU on working conditions.

59. Communication of 19 October 2020, 'Commission Work Programme 2021' (COM(2020) 690).

60. Proposal for a Directive of the European Parliament and of the Council on improving working conditions in platform work $\operatorname{COM}(2021) 762$ final 2021/0414.

61. CEPS, EFTHEIA and HIVA-KU Leuven, 'Study to Gather Evidence on the Working Conditions of Platform Workers' (VT/2018/032 Final Report 2020). 
The personal scope of the new Directive is already a matter of controversy. In fact, the minimum rights laid down in the Directive apply to "every worker in the Union who has an employment contract or employment relationship as defined by the law, collective agreements or practice in force in each Member State with consideration to the case law of the Court of Justice' (emphasis added). ${ }^{62}$ As long as they fulfil the criteria established by the CJEU, domestic, on-demand, intermittent, voucher-based and platform workers, trainees and apprentices fall within the scope of this Directive and are entitled to a set of minimum rights. ${ }^{63}$ This 'hybrid' formula, which has led to disagreement between the co-legislators, combines Member States' autonomy in defining the legal determinants of an employment relationship (a practice limiting a uniform application of the EU social acquis) with consideration for the CJEU's case law. ${ }^{64}$ The risk is that some Member States could opt for a 'conservative' personal scope. Yet, a broad interpretation of the Directive's protective aims could lean towards the inclusion of non-standard workers in a purposive way. ${ }^{65}$ Consequently, platform workers would fall within the scope of the measures laid down in the Directive. Interestingly, the legal classification of workers could represent both a battlefield and an opportunity for successful dialogue between courts at different levels.

Workers whose work patterns are 'entirely or mostly unpredictable' (Art. 10) must be informed about the variable organisation of their work and the number of guaranteed paid hours. They also have a right to be informed on how they will be paid for any additional hours worked when exactly their work will commence within a reasonable notification period and the timeframe within which an agreed assignment can be cancelled. These provisions purport to re-standardise casual work by designing a stable availability window, outside which workers cannot be penalised for refusing to show up and within which must be compensated if a previously agreed slot is cancelled. In a sense, this set of rules sends a clear message about the need to avoid a downward spiral, accelerated by increasingly popular models that shift business risks to casual workers.

The set of minimum requirements relating to working conditions is particularly noteworthy. ${ }^{66}$ Some of them seem to have been conceived to prevent abuse in the most volatile segments of the platform economy. Simultaneous engagements with other employers are allowed, i.e. the worker will not be treated adversely, and at the same time incompatibility clauses must be limited (Art. 9). Considering the balanced rationale of enhancing transparency and predictability while maintaining a reasonable degree of flexibility for non-standard employment, these concessions are problematic on two grounds. On the one hand, several platforms include non-exclusivity clauses - which often remain on paper - to reinforce their legal arguments on the supposed autonomy enjoyed by the worker. On the other, legitimising the practice of taking multiple jobs could

62. The same formula is used in Directive (EU) 2019/1158 of the European Parliament and the Council of 20 June 2019 on work-life balance for parents and carers and the new Commission proposal for a Directive on adequate minimum wages. See Elisa Chieregato, 'A Work-Life Balance for All? Assessing the Inclusiveness of EU Directive 2019/1158' (2020) 36(1) Int J Comp Lab Law Ind Relat 59.

63. Regardless of the number of hours worked, workers who have no guaranteed working time, including zero-hours and some on-demand contracts, should fall under the scope of the Directive.

64. Bartlomiej Bednarowicz, 'Delivering on the European Pillar of Social Rights: The New Directive on Transparent and Predictable Working Conditions in the European Union' (2019) 48 Ind Law J 604.

65. Martin Risak and Thomas Dullinger, The Concept of "Worker" in EU Law: Status Quo and Potential for Change (ETUI Research Paper 2018).

66. For a critical comment, see Agnieszka Piasna, Regulating Uncertainty: Variable Work Schedules and Zero-Hour Work in EU Employment Policy (ETUI Policy Brief 2019). 
lead to further work intensification. Workers agree to work on multiple tasks, assignments and projects because they are left with no choice if they are to earn a meaningful level of pay. The worker's questionable voluntary choice should not find technical encouragement and tolerance.

The Directive envisages a set of rules aimed at preventing and fighting abuses, which may include limitations to the use and duration of on-demand contracts-in line with similar provisions included in the framework agreement on fixed-term work-or a rebuttable presumption regarding the existence of an employment contract or employment relationship (Art. 11). This is a strong legal instrument-already in force in some Member States-to deter employers from implementing casual work without restraints. There are two main approaches to designing such an instrument: (i) a broad presumption that all relationships are subordinate and that a worker making a claim is not required to produce evidence supporting the allegation; (ii) a reversal or reduction in the distribution of the burden of proof for workers based on one or several factual indicators in a specific case, in line with ILO R198 according to which 'Members should [...] consider the possibility of [...] (b) providing for a legal presumption that an employment relationship exists where one or more relevant indicators is present'. ${ }^{67}$

\section{B. Council Recommendation on Access to Social Protection for Workers and the Self-employed: Too early to judge}

The traditional social protection model-premised upon the archetypal full-time, open-ended relationship or contract between a worker and a single employer over a long time span-is under-inclusive and fails to be adaptable when it comes to providing income over the life cycleand mitigating the risks of poverty and social exclusion among the self-employed and their families. As a result, '[w]orkers in non-standard forms of employment are often not covered, or only partially covered, by social protection systems, particularly employment-based schemes. ${ }^{, 68}$

Access to social protection is denied for several forms of under-protected work. In some Member States, those working in the platform economy may be excluded from certain social security schemes (particularly, accidents at work, sickness and unemployment benefits) because of their employment status. For instance, platform workers may not meet the minimum criteria to access contribution-based benefits in case of need (such as qualifying periods, waiting periods, minimum working periods and duration of benefits) due to the intermittent and low-income nature of their engagements. Non-standard workers are ideal beneficiaries of policies aimed at reinforcing the social safety net to protect individuals against the economic implications of social risks, such as illness, old age, accidents at work and unemployment - a need that has become even more tangible during the Covid-19 pandemic. Likewise, these workers would benefit considerably from measures preventing and alleviating poverty and upholding a decent standard of living.

67. Paragraph 11, R198 - Employment Relationship Recommendation, 2006 (No. 198). See also Garben S. (2021), 'Old' rules and protections for the 'new' world of work, available at: https://socialeurope.eu/old-rules-and-protections-for-thenew-world-of-work. Garben S. (2019). Tackling social disruption in the online platform economy. FEPS Policy Paper.

68. Christina Behrend and Quynh Anh Nguyen, Innovative Approaches for Ensuring Universal Social Protection for the Future of Work (ILO Future of Work Research Paper Series 2018). See also Mark Stuart and others, The Social Protection of Workers in the Platform Economy (European Parliament 2017); OECD, The Future of Social Protection: What Works for Non-Standard Workers? (OECD 2018). 
The Recommendation, ${ }^{69}$ which does not apply to social assistance and minimum income protection schemes, invites Member States to tailor the rules to the situation of the specific groups while maintaining a general principle of universality. Member States have committed themselves to ensure effective, adequate coverage for all workers and the self-employed. When it comes to platform workers, Member States are expected to grant access to adequate social protection in numerous ways. For instance, they could review the rules governing contributions and entitlements to ensure that they do not constitute undue obstacles to access to benefits for those who perform work of an exceedingly low duration, generating overly limited earnings. A possible response could be the incorporation into existing schemes of non-standard workers who combine various engagements. Multiple contributions to overlapping schemes, which today represents a common shortcoming, must be avoided. On a positive note, the creation and maintenance of interoperable public databases can increase transparency, verifiability and compliance. Member States are encouraged to guarantee that entitlements are preserved, accumulated and/or transferable across all types of statuses and industries throughout the person's career. Efficient, adaptable, transferable and user-friendly solutions must be implemented for all forms of employment that diverge from the classical scheme. In this respect, 'data-driven' solutions represent an opportunity to enhance formalisation and reduce administrative complexity, as they can facilitate registration and collection while avoiding fraud and errors. ${ }^{70}$

\section{The Elephant in the Room: The EU Social Acquis in the 'First Round' of Legislation on Atypical Employment}

Platform workers do not necessarily need new regulations but rather more effective enforcement and an unambiguous legal framework. EU institutions have a long tradition of regulatory involvement in atypical employment. Thus, every new initiative must entail a careful impact assessment of existing schemes and, possibly, their application or revision.

Notably, the EU social acquis on atypical employment represents the most regulated province in the region of non-standard work. However, as recognised by Bell, the risk is a stark polarisation between 'typified-atypical' workers and 'new' or 'very' atypical working templates. ${ }^{71}$ This is also because the three Directives examined below have been followed by a long phase of inaction, and the momentum of integration in the social field has weakened. However, despite their inevitable shortcomings, the three Directives regulating atypical employment at the EU level represent good practices in terms of both legislative techniques (in the first two cases, they gave binding force to an agreement previously signed by EU social partners) and substantive norms. ${ }^{72}$

69. Recommendation of 8 November 2019 on access to social protection for workers and the self-employed (2019/C 387/ $01)$.

70. Dominique La Salle and Greta Cartoceti, Social Security for the Digital Age: Addressing the New Challenges and Opportunities for Social Security Systems (International Social Security Association 2019). See also Proposal to revise the Directive on Administrative Cooperation (Directive 2011/16/EU; COM(2020) 314 final).

71. Mark Bell, 'Between Flexicurity and Fundamental Social Rights: The EU Directives on Atypical Work' (2012) 1 Eur Law Rev 31. See also Andrea Broughton and others, Flexible Forms of Work: 'Very Atypical' Contractual Arrangements (EurWork Observatory 2010).

72. Mark Jeffery, 'Not Really Going to Work? Of the Directive on Part-Time Work, "Atypical Work" and Attempts to Regulate It' (1998) 27(3) Ind Law J 193. 


\section{A. Part-time, Fixed-term and Temporary Agency Work Directives: new wine in old bottles?}

Platform work resembles some non-standard forms of employment: the work activity is divided into small tasks and performed as multiple ad hoc transactions, and at least three parties are involved in a single operation. Commonly referred to as Directives on atypical work, the three different initiatives established a set of guiding principles later implemented at the domestic level. All the Directives institute a general principle that workers who fall within their scope are not ill-treated and discriminated; however, the lowest common denominator agreed on by all Member States is based on a minimalist approach. While each Directive lays down some specific provisions, the rationale behind these policies seems to be recourse to equal treatment 'as a means to improve quality of these forms of employment. ${ }^{73}$ There are conflicting views on the Directives' meaning and merit, yet the objectives of the first two Directives are manifest and twofold. On the one hand, they attempt to remove discriminatory obstacles, thus encouraging voluntary part-time work (PT) and contributing to the flexible organisation of work to benefit both employers and employees. ${ }^{74}$ On the other, the goal is to also limit abuse of renewals of (successive) fixed-term contracts (FT) ${ }^{75}$ Regarding temporary agency work (TAW), the objectives include strengthening legal protection and improving the quality of work of temporary agency workers, with the aim of supporting the creation of jobs and the development of flexible arrangements. ${ }^{76}$ Therefore, caution is essential when it comes to assessing their relevance for platform workers; the three Directives on atypical employment cannot be treated as a monolith. In fact, a promotional intervention for PT work is balanced by the abuse prevention purpose of the Directive on FT work. Similarly, the intervention on TAW was meant to harmonise the protection of so-called 'temp' workers (through the equal treatment principle), contributing to job creation and the development of flexible forms of work.

There is another way of looking at this area of law, namely, from the perspective of the so-called comparable worker, which 'has proved to be the Achilles heel of EU equality law in general'. ${ }^{77}$ In particular, the Framework Agreement on PT work prohibits part-time workers from being treated less favourably than full-time workers, whereas the Framework Agreement on FT work lays down the principle of equal treatment between fixed-term and permanent workers. In the case of workers who have concluded a PT contract, the primary 'comparator' is a full-time worker in the same establishment with the same type of employment contract or relationship. ${ }^{78}$ Likewise, for fixed-term workers, the main comparator is a worker with an employment contract or relationship of indefinite duration in the same establishment. When there is no comparable full-time or permanent worker in the same establishment, the Directive mentions that comparison shall be made with reference to the applicable collective agreement or, where none has been concluded, in accordance with national

73. Ibid [72].

74. Council Directive 97/81/EC of 15 December 1997 concerning the Framework Agreement on part-time work concluded by UNICE, CEEP and the ETUC.

75. Council Directive 1999/70/EC of 28 June 1999 concerning the framework agreement on fixed-term work concluded by ETUC, UNICE and CEEP.

76. Directive 2008/104/EC of the European Parliament and of the Council of 19 November 2008 on temporary agency work.

77. Nicola Countouris, 'EU Law and the Regulation of 'Atypical' Work, in A. Bogg and others and others (eds.), Research Handbook on EU Labour Law (Edward Elgar Publishing 2016) 246.

78. However, the Directive on part-time work allows Member States, after consulting its social partners, to exclude casual work from the personal scope of application for objective reasons. 
law, collective agreement or practice (Clause 3 (2) of the two Framework Agreements). According to the Directive on TAW, the working and employment conditions of agency workers need to be 'at least' the same for the duration of their assignment as those that would apply to workers directly recruited for the same job in the user firm (not necessarily hired on a full-time contract) (Art. 5(1)). The Directive specifies that 'basic working and employment conditions' relate to: (i) the duration of working time, overtime, breaks, rest periods, night work, holidays and public holidays; and (ii) pay (Art. 3(1)). ${ }^{79}$

In principle, a comparison can easily be drawn where the platform operates to benefit firms employing a stable workforce. Regrettably, in an 'asset-light' firm operating exclusively through self-employed platform workers, the 'benchmarking activity', which is an essential part of the equality test, can be extremely complex and burdensome, thus making the identification of a comparator gruelling, especially when collective agreements are not sufficiently inclusive and up-to-date. This situation may unduly affect platform work, as has been the case for casual workers in the recent past. ${ }^{80}$ However, the 'delegation' included in the Framework Agreements on PT and FT could contribute to converging platform workers' terms and conditions with those of workers employed under standard contracts in the same sectors (e.g. trade, logistics, transport and services). This possibility could pave the way for genuine solidarity among long-established trade unions, which could take action to improve platform workers' working conditions by embodying the abstract position of the comparator in new encompassing collective agreements.

The next question is whether the personal scope of the three Directives is broad enough to encompass platform workers. The Directives suffer from some of the limitations deriving from the rigid dichotomy between employment and self-employment. Both protocols apply to PT and FT workers hired under an employment contract or relationship defined in law, collective agreements or practice in each Member States (Clause 2(1)). This requirement conflicts with the common classification imposed by platforms, which qualify workers as self-employed persons. As discussed in the prevision section, in many EU jurisdictions this question must be objectively determined with reference to the reality of the working arrangement based on a long list of 'symptomatic indexes'. Courts can rectify misclassification, and platform workers may fall under the personal scope of the Directives in case of successful litigation. ${ }^{81}$ However, this process can be expensive and time-consuming, while the outcome may be unpredictable.

The Parliamentary Resolution on a European Agenda for the collaborative economy states that 'many intermediating online platforms [are] structurally similar to temporary work agencies (triangular contractual relationship between: temporary agency worker/platform worker; temporary work agency/online platform; user undertaking/client)', and calls on the Commission to examine the extent to which Directive 2008/104/EC is applicable to specific online platforms (para. 46). Some scholars have proposed an analogous intervention for workers in multiparty arrangements, predominantly_albeit not exclusively_focusing on 'crowdwork' (i.e., services that are completed

79. The Directive provides for a set of derogatory measures that can be implemented at the national level after consulting social partners and as long as an adequate level of protection is guaranteed.

80. In a case concerning an 'on-demand contract', the CJEU ruled that there was no 'comparator' in the enterprise because all the full-time workers had fixed hours and were required to work without the option to refuse it. Case C-313/02, Nicole Wippel v Peek \& Cloppenburg GmbH \& Co. KG [2004] ECLI:EU:C:2004:607.

81. Sasha Garben, Protecting Workers in the Online Platform Economy: An Overview of Regulatory and Policy Developments in the EU (Publications Office of the European Union 2017). 
remotely and delivered online). ${ }^{82}$ Critics, however, have noted shortcomings of this approach, as it is fraught with seemingly insurmountable difficulties. In the various sectors of location-dependent platform work, this would mean creating dozens of commercial contracts between the online platform and the final customers. In a way, paradoxically, this would also crystallise the expansion of the sources of managerial prerogatives exercised over workers, thus intensifying the control regime without responsibility.

The relationship between parties can be described as a triangular one, and the platform's role could be equated with that played by a traditional 'broker'. However, the fully-fledged and automatic application of the Directive raises many problems from practical and legal perspectives. Indeed, the Directive aims to offer minimal protection to temporary agency workers by establishing the principle of equal treatment and identifying temporary work agencies as employers. It is worth noting that this legal template is characterised by the existence of two different contracts: a commercial one binding both the agency and the final user as well as an employment contract (or relationship) between the agency and the worker. Thus, for the purpose of the application of the Directive, the contentious legal status of platform workers is still relevant. Despite the judicial attempts to broaden the personal ambit of application due to a wide and flexible interpretation of the notion of 'worker' (further discussed below), only workers under a contract of employment or who are in an employment relationship with a temporary work agency fall under the scope of the Directive on TAW (Art. 3(1)). Nevertheless, national employment law systems do not have 'unfettered discretion in deciding who is to be seen as a worker and what a contract or relationship amount to' ${ }^{83}$ Moreover, in the original model, a worker is assigned to a user undertaking to work under the supervision and direction of the latter temporarily. From a functional perspective, this would reduce the intervention exercised by the platforms, as many of them currently directly organise and control the workforce. Lastly, a licensing system is often in place: agencies must meet several operational and financial requirements. The stringent regulation of the sector is leading to opposition among incumbent temporary work agencies, already heavily digitalised, that feel their business is imperilled by those platforms that are competing deceitfully.

Although there may be some organisational similarities, mainly due to the trilateral interaction, the respective characteristics nevertheless reveal that TAW and platform work are two different formats. Against that backdrop, the application of the TAW scheme to platform work is not straightforward. This policy solution may not 'resolve the questions as to who the contractual partners are or under what contract the work is performed. Furthermore, it does not facilitate enforcement of the rights of platform workers. ${ }^{84}$ Besides this, from a tactical standpoint, one may find it difficult to understand why a worker should bring a claim to be reclassified as a worker for the purpose of the TAW Directive with the sole purpose of benefitting from a regime to which a (modest) equality principle applies rather than demanding a straightforward reclassification. It is often neglected that the Directive in question cannot apply to situations in which the user undertaking is not engaged in economic activities. Many 'requesters' act as private persons and may not have any other employee,

82. Luca Ratti, 'Online Platforms and Crowdwork in Europe: A Two-Step Approach to Expanding Agency Work Provisions' (2016) 38(2) Comp Lab L \& Pol'y J 477.

83. Nicola Countouris and others, Report on Temporary Employment Agencies and Temporary Agency Work: A Comparative Analysis of the Law on Temporary Work Agencies and the Social and Economic Implications of Temporary Work in 13 European Countries (ILO European Union European Social Fund 2016).

84. Martin Risak, Fair Working Conditions for Platform Workers. Possible Regulatory Approaches at the EU Level (Friederich Ebert Stiftung 2017). 
thus undermining the process of comparison. To conclude, although requiring some digital platforms to operate as temporary work agencies could prove arduous, it is a workable option. This would not, however, be a panacea for platform workers. ${ }^{85}$

Overall, the EU regulatory solutions for atypical employment indicate that classifying workers as employees does not entail a loss of business flexibility. There is no incongruity between labour regulation and unorthodox organisational patterns. It is not simply a case of institutions having to revise these three Directives on atypical employment to meet the demands of certain digital platforms. Rather, it should be a process of adapting self-proclaimed 'innovative' business models to the various flexible solutions offered by the existing EU and domestic legal framework. There are indications that this is already taking place in some industries. ${ }^{86}$ Therefore, it is crucial to strive to go beyond this 'shoot first and ask questions later' logic. As argued elsewhere, ${ }^{87}$ the inherent flexibility of the employment contract or relationship, granted by the abovementioned atypical formats, allows the full deployment of the managerial strategies while enabling novel arrangements made possible by digital transformation. The goal should be a labour market where innovation is a synonym for not only flexible jobs but also sustainable and high-quality ones.

\section{B. Is There any Room for the CJEU to Classify Platform Workers as 'Workers'?}

Platform work is now ubiquitous throughout the EU. This notwithstanding, the current state of exception risks morphing into a blank proxy for deregulation processes that disavow the existing legal system, nullifying any attempt to offer adaptable solutions that accommodate the needs of a changing labour market. ${ }^{88}$ The purpose of this section is to examine the possibility of the CJEU classifying (some) platform workers as workers. Several strands of analysis are entwined. First, it is necessary to develop effective tools to increase familiarity with the functioning of platform-organised arrangements, considering the potential of management by algorithms, which both augments and diffuses employer authority. ${ }^{89}$ Second, based on this thorough assessment, it is crucial to wisely consider the factual circumstances of the performance by interpreting the notion of 'subordination' in an evolving way. Third, for the time being, this reasoning must be incrementally developed by adopting a sector-specific and case-by-case approach. ${ }^{90}$

There is still widespread uncertainty over the classification of platform workers. New technologies, which purport to create an emancipating new reality of work, are often used to deepen

85. Nastazja Potocka-Sionek, 'The Changing Nature of Labour Intermediation. Do Algorithms Redefine Temporary Agency Work?' in Wratny J. and Ludera-Ruszel A. (eds.), News Forms of Employment (Springer VS 2020) 169.

86. Jonathan Josephs, Just Eat to Stop Using Gig Economy Workers (2020), available at: https://bbc.in/32oWaay.

87. Antonio Aloisi and Valerio De Stefano, 'Regulation and the Future of Work: The Employment Relationship as an Innovation Facilitator' (2020) 159(1) Int Lab Rev 47.

88. Veena B. Dubal, 'AB5, Economic Security \& the Regulation of Gig Work in California', Thematic Working Paper for the 2020 Workshop of the European Centre of Expertise (ECE) in the Field of Labour Law, Employment and Labour Market Policies: Exploring Ways to Improve Working Conditions of Platform Workers: The Role of EU Labour Law (2020).

89. Alex J. Wood and others. 'Good Gig, Bad Gig: Autonomy and Algorithmic Control in the Global Gig Economy' (2019) 33(1) WES 56; Alexandra Mateescu and Aiha Nguyen, 'Algorithmic Management in the Workplace' (2019) Data Soc 1.

90. Case C-256/01, Debra Allonby v Accrington \& Rossendale College [2004] ECLI:EU:C:2004:18 (explaining that 'there is no single definition of worker in Community law: it varies according to the area in which the definition is to be applied'). See Koen Lenaerts, 'EU Citizenship and the European Court of Justice's 'Stone-by-Stone' Approach' (2015) 1(1) Int Comp Jurisprud 1. 
hierarchy and control, despite the regulatory efforts to limit the unrestrained adoption of automated decision-making processes. Deceitful, distributed and pervasive forms of control are not complemented by the activation of counterweights defined by the legislator or collectively negotiated by social partners. Though some alternative working patterns may not meet the rigid national requirements or formalities defined by law or case law, most situations are a neat fit with existing legal schemes. ${ }^{91}$ Indeed, this reality lies in stark contrast with the rhetoric of self-employment and entrepreneurship, as platform workers often have limited control over their working conditions. When managerial prerogatives are exercised by means of digital tools, such as scheduling software, geolocation devices or rating systems outsourced to clients, the worker's limited flexibility in deciding whether, when and where to provide the service should not exclude the possibility of the latter having access to the protective regime of labour law. ${ }^{92}$

Moreover, the current binary divide should not be regarded as exclusionary as it does not prevent self-employed workers from being granted some basic labour and social rights. Indeed, various legal systems afford a minimum amount of protection to self-employed persons. ${ }^{93}$ However, in most EU Member States, the dominant notion of 'worker' is shaped by reference to the concept of 'subordination'. ${ }^{94}$ In the same vein, the EU concept of 'worker' is still associated with the technical and legal situation of subjection, which materialises when an activity is performed 'under the direction or supervision' of an employing entity. While the Directive on transparent and predictable working conditions is a step in the right direction, as it refers to the CJEU's evolving case law, much remains unknown about how the Court will approach the interpretation of the concept of 'worker' in an increasingly digitalised and dematerialised economy.

Notably, there is a trend towards a Europeanisation of the definition of worker. This trend has resulted in the development of an almost independent meaning of the term 'worker', which was originally established by the CJEU to expansively define the scope of the fundamental freedom of the movement of workers. ${ }^{95}$ The purpose is to avoid endangering uniformity at the domestic level by restrictive transpositions excluding certain forms of work from the application of EU labour law. For instance, in defining the scope of the application of Directive 2008/104, the Court has claimed that the personal scope of application of EU labour law tools 'ought to be, ultimately, a matter for EU law to define'. ${ }^{96}$ The CJEU has repeatedly held that 'the essential feature of an employment relationship is that, for a certain period of time, a person performs services for and under the direction of another person, in return for which he receives remuneration, the legal characterisation under national law and the form of that relationship, as well as the nature of the legal

91. There are strong indications of a command-and-control position held by the platform, resulting in a model more 'effective than management based on formal orders given by an employer to his employees and direct control over the carrying out of such orders'. Opinion of A. G. Szpunar, Case C-434/15 Asociación Profesional Elite Taxi v Uber Systems Spain, SL [2017] ECLI:EU:C:2017:364.

92. Valerio De Stefano, 'A More Comprehensive Approach to Platform-Work Litigation' (Regulating for Globalization 2018), available at https://bit.ly/2HC1KiY.

93. Guy Davidov, 'Setting Labour Law's Coverage: Between Universalism and Selectivity' (2014) 34(3) Oxf J Leg Stud 543.

94. Stefano Giubbini, 'Being a Worker in EU Law' (2018) 9(3) Eur Lab Law J 223.

95. Case C-66/85, Deborah Lawrie-Blum v Land Baden-Württemberg [1986] ECLI:EU:C:1986:284. See also Case C-428/ 09, Union syndicale Solidaires Isère v Premier ministre and Others [2010] ECLI:EU:C:2010:612.

96. Nicola Countouris, 'The Concept of "Worker" in European Labour Law: Fragmentation, Autonomy and Scope' (2018) 47(2) Ind Law J 192. 
relationship between those two persons, not being decisive in that regard' ${ }^{97}$ This position corroborates the principle of the prevalence of substance over form (the 'primacy of reality' doctrine). What is more, according to settled case law, the control test can also be passed in case of tenuous elements of subordination. ${ }^{98}$ Thanks to its institutional legitimacy, the CJEU has progressively adopted a wide-ranging, persistent and relaxed notion of subordination, which 'does not require an employer to be constantly watching over the shoulders of a worker' ${ }^{99}$

Moreover, in Allonby, the Court clarified that the formal classification of a self-employed person under national law does not exclude the possibility that 'a person must be classified as a worker [within the equal pay provisions of Article $157 \mathrm{TFEU}$ ] if his or her independence is merely notional. ${ }^{, 100}$ The CJEU has emphasised the importance of the factual relationship beyond the formal appearances and terms of the contract. At the same time, it has strengthened its prerogative to 'surpass' the domestic classification in case it does not accurately reflect the reality of the work performance (sham self-employment). ${ }^{101}$ However, recently confronted with a case on the application of the social acquis on working time regulation to non-standard workers, ${ }^{102}$ while confirming the need to move beyond a formalistic approach based on the letter of the contract, the CJEU did not go so far as to provide useful elements to update the classical analysis.

In a case concerning the interpretation of the Directive on PT work, the CJEU held that while 'it is for the Member States to define the concept of workers who have an employment contract or an employment relationship' and to determine who falls within that concept, this process is 'subject to the condition that that does not lead to the arbitrary exclusion of [a given] category of persons from the protection offered by [the] Directive. ${ }^{103}$ Indeed, as explained in the same ruling, 'the discretion granted to the Member States [...] is not unlimited. [...] Certain words used in that agreement may be defined in accordance with the national law and practices on condition that they respect the effectiveness of the Directive and the general principles of European Union law'. A lack of application of EU rules is 'liable to jeopardise the achievement of the objectives pursued by a Directive and, therefore, deprive it of its effectiveness' (para 35).

As has been rightly pointed out, '[i]t would seem harmful to the social objectives of the acquis if its scope of application could be unilaterally limited by the Member States, excluding certain forms of work or workers regardless of the material conditions of their employment. ${ }^{104}$ In the near future, this pragmatic approach to the definition of a more autonomous meaning of the concept of 'worker' ought to be applied by transcending the areas where it has been traditionally adopted (internal

97. Case C-216/15, Betriebsrat der Ruhrlandklinik v Ruhrlandklinik [2016] ECLI:EU:C:2016:518.

98. Case C-232/09, Dita Danosa v LKB Lizzings SIA [2010] ECLI:EU:C:2010:674. See also Luca Nogler, The Concept of 'Subordination' (Università degli Studi di Trento 2009).

99. Ibid [96].

100. Case C-256/01, Debra Allonby v Accrington \& Rossendale College [2004] ECLI:EU:C:2004:18; Case C 413/13, FNV Kunsten Informatie en Media $v$ Staat der Nederlanden [2014] ECLI:EU:C:2014:2411.

101. In line with R198 - Employment Relationship Recommendation (No. 198) [2006] ('[t]he determination of the existence of such a relationship should be guided primarily by the facts relating to the performance of work and the remuneration of the worker, notwithstanding how the relationship is characterized in any contrary arrangement, contractual or otherwise, that may have been agreed between the parties.').

102. Case C-692/19, B v Yodel Delivery Network Ltd [2020] ECLI:EU:C:2020:288. See Antonio Aloisi (2020), “Time Is Running Out". The Yodel Order and Its Implications for Platform Work in the EU' (2020b) 13(2) ILLeJ 67.

103. Case C-393/10, Dermod Patrick O'Brien v Ministry of Justice [2012] ECLI:EU:C:2012:110.

104. Sasha Garben and others, Towards a European Pillar of Social Rights: Upgrading the EU Social Acquis (Policy Briefs No. 1, College of Europe 2017). 
market law, freedom of movement, equal pay, anti-discrimination, working time, pregnant workers and collective redundancies). The drafting of a cohesive, modern and ample notion of 'worker' could be presented by means of a new Directive amending the scope of the existing ones (or at least some of them) horizontally or through the CJEU's adaptable interpretation - an option that could prove to be future-friendly. Such a knock-on effect should be encouraged to ensure that EU institutions embark on a new chapter of consolidating the social acquis, managing its achievements and adapting them to the fast-changing world of work. The gradual strengthening of this unified concept would foster a uniform and consistent application of EU law, ${ }^{105}$ improving legal certainty and programmability for all sides.

European labour law cannot be considered an à la carte menu: a consistent application is recommended. This is a fertile line of law-making and judicial intervention that should be developed without weakening the discretion granted to Member States in designing their own measures in the social field. As such, the pressing question is how ready EU institutions are to take on this challenge based on the Social Policy Title. The more technology advances, the more urgent the need to strengthen social institutions. The EPSR and its roll-out initiatives can also address current constitutional imbalances between the different dimensions of the EU, namely, the market and the social.

\section{Final Remarks and Policy Recommendations}

Courts, inspectorates and policymakers are effectively closing loopholes in enforcement after years of perilous doublespeak and uncertain litigation. This renewed institutional activism will hopefully trigger the implementation of a stronger social agenda promoting the rights of workers, regardless of their debatable classification. ${ }^{106}$ Delivering positive outcomes for platform workers requires combined efforts. A coordinated and multi-pronged response is the preferable option for mitigating the risk of arbitrage and jurisdiction shopping in the EU. However, regulators need to resist the idea of a homogenous form of work deserving of narrow interventions. Aside from being prone to rapid obsolescence, tailor-made solutions could potentially perpetuate a dualism between different forms of employment, leaving too many aspects poorly regulated. ${ }^{107}$ This phenomenon must urgently be adapted to existing legal frameworks before exploring sui generis regulatory responses, which are ultimately doomed to fail. ${ }^{108}$ Indeed, many problems that platform workers face, such as questions about the proper classification of their employment status, access to collective bargaining or social protection, also affect other vulnerable forms of employment, particularly dependent selfemployment and casual work. Therefore, the most pressing challenge is 'to adapt socio-legal model by adopting more encompassing, future-oriented and elastic solutions instead of addressing

105. According to the Preamble of the EPSR, 'Where a principle refers to workers, it concerns all persons in employment, regardless of their employment status, modality and duration'. See also Monika Szpejna and Zahra Boudalaoui-Buresi, The Scope of EU Labour Law, Publication for the Committee on Employment and Social Affairs, Policy Department for Economic, Scientific and Quality of Life Policies (European Parliament 2020).

106. European Pillar of Social Rights, Chapter II: Fair Working Conditions, Fifth Principle. See also Art. 31, Charter of Fundamental Rights of the European Union (2012/C 326/02).

107. Simon Deakin, 'New Forms of Employment: Implications for EU-law-The Law As It Stands' in European Labour Law Network - $7^{\text {th }}$ Annual Legal Seminar (ELLN 2014).

108. Jeremias Prassl and Martin Risak M. (2016), 'Uber, Taskrabbit, and Co.: Platforms as Employers - Rethinking the Legal Analysis of Crowdwork' (2020) 37(3) Comp Lab L \& Pol'y J 619. Ursula Huws, Reinventing the Welfare State: Digital Platforms and Public Policies (Pluto Press 2020). 
merely platform work. ${ }^{109}$ A feasible, ambitious solution could be the adoption of a Directive that ensures equal treatment between all forms of non-standard and standard work. ${ }^{110}$

At the institutional level, the European Labour Authority (ELA) could be ascribed specific assignments in this regard to advance its position as a continental labour inspectorate by ensuring a more effective application and enforcement of relevant EU law. ${ }^{111}$ Undeclared work, often dovetailing together with platform work in some sectors, is established within the Authority's remit. Thus, given its broad power, the Authority is expected to address the implications of the crossborder character of certain forms of platform work by means of concerted or joint inspections. It must be noted, however, that the situation is less troubling for location-dependent workers, as significance is assigned to the notion of the 'habitual place of work' or 'habitual residence' in determining the applicable law. ${ }^{112}$ Under EU law, the choice of jurisdiction and/or law applicable to employees' individual contracts may not result in inferior protection, which they would otherwise be entitled to in the absence of such choice in their contract.

In the face of mounting evidence of the expansion of the 'grey area' between employment and self-employment, leading to ambiguous legal situations and barriers in terms of access to social rights, labour inspectorates, which are often underfunded and understaffed, could assume a more proactive role in enforcing existing rules at the domestic level. This could be achieved by fostering capacity building and training, developing new operative procedures, implementing pilot programmes and sharing best practices. To fight the propensity for deception, authorities could define a set of criteria to facilitate the detection of bogus self-employment, which raises the following issue.

The possibility of introducing a rebuttable presumption of the existence of an employment relationship is being considered to effectively tackle the risk of misclassification in line with the new Directive on transparent and predictable working conditions and ILO R198. ${ }^{113}$ There are two main ways to implement such a presumption: (i) presuming that all relationships are employment relationships and shifting the burden to prove otherwise on the principal - the radical option; and (ii) easing the burden of proof by selecting one or several criteria that prove the existence of an employment relationship in a case before tribunals, labour inspection authorities or tax collecting offices - the moderate option. Since platform workers may 'lack the necessary information to be able to reliably judge their own status', ${ }^{114}$ the burden of proof for determining the existence of an employment relationship could be streamlined by identifying some key indicators of subordination. A more open and explicit reliance on elements such as 'organisation by the other party', 'personal work' or 'business integration' could represent a viable solution in several EU jurisdictions,

109. Nastazja Potocka-Sionek and Antonio Aloisi (2021), “Festina Lente": The ILO and EU Agendas on the Digital Transformation of Work' (2021) 37 Int J Comp Lab Law Ind Rel 35.

110. Harald Hauben and others, 'Platform Economy and Precarious Work: Mitigating Risks' (Directorate-General for Internal Policies 2020).

111. Jean-Philippe Lhernould (2020), 'Intra-EU Cross-Border Platform Work: Hiding Issues of Undeclared Work' (2020) 70(4) Zbornik Pravnog fakulteta u Zagrebu 455.

112. Regulation (EC) No 593/2008 of the European Parliament and of the Council of 17 June 2008 on the law applicable to contractual obligations (Rome I). See Miriam A. Cherry, 'Regulatory Options for Conflicts of Law and Jurisdictional Issues in the On-Demand Economy' (ILO 2019) 106.

113. Valerio De Stefano and others, Platform Work and the Employment Relationship (International Labour Organization 2021).

114. BMAS (Federal Ministry of Labour and Social Affairs), 'Key Issues Paper, Work in the Platform Economy' (2020), available at https://bit.ly/3n6hj0T. 
whose courts are already familiar with these indicators. The burden of proving that an employment relationship does not exist would rest with the platform operator. This measure would help vulnerable workers claim their employment rights, thus balancing the contractual parties' unequal bargaining power and contributing to legal certainty.

At the same time, the General Data Protection Regulation could be counted on to ensure the transparency, accuracy and fairness of rating, evaluation and classification systems, and to provide redress mechanisms in cases of perceived capricious treatment. These are among workers' most urgent concerns. ${ }^{115}$ Recently, several lawsuits were filed in the Netherlands (Uber's European headquarters is based in Amsterdam) by former drivers claiming that algorithms automatically determined which drivers should be removed from the platform in a non-transparent way and with no meaningful human intervention, thus breaching Articles 15 and 22 of the GDPR (which sets down data access rights and the right to not be subject to automated decisions without human involvement, including profiling, which produces legal effects for the individual or significantly affects him or her). ${ }^{116}$

For those platform workers who are genuinely autonomous, the Platform to Business Regulation on promoting fairness and transparency for business users of online intermediation services can offer reliable safeguards, ${ }^{117}$ leading to a more competitive online ecosystem. For all workers, the rating accrued on a platform, as well as the work history that has led to that rating, must be transferable to avoid the lock-in effect. Interoperability with the profiles on other platforms must be ensured. Any exclusivity clauses must be banned or, if they continue to apply, must be considered non-competition clauses and properly compensated. ${ }^{118}$

The challenge for the future is to reinvent social protection models by adopting more flexible solutions based on the transferability and interoperability of acquired social rights instead of implementing exemptions and exclusions, which may end up converting non-employment formats into low-cost alternatives. International institutions recommend moving towards a system based on the universality of protection and accessibility, transparency and predictability of entitlements, the promotion of gender equality, adequacy and the sustainability of schemes. During the pandemic, some measures extended traditional social protection to platform workers in a universalistic fashion, albeit only temporarily. This opportunity should be capitalised on to extend comprehensive protection to non-standard workers in an incremental, systemic and permanent manner.

115. Regulation (EU) 2016/679 of the European Parliament and of the Council of 27 April 2016 on the protection of natural persons with regard to the processing of personal data and on the free movement of such data (General Data Protection Regulation). Michael S. Silberman and Hannah Johnston, 'Using GDPR to Improve Legal Clarity and Working Conditions on Digital Labour Platforms. Can a Code of Conduct as Provided for by Article 40 of the General Data Protection Regulation (GDPR) Help Workers and Socially Responsible Platforms?' (Working Paper 05, ETUI 2020).

116. Paul Sawers, 'Uber Drivers Union Asks EU Court to Overrule "Robo-Firing” by Algorithm' (VentureBeat 2020), available at https://bit.ly/3a7ox1Z. Natasha Lomas (2021), 'Dutch Court Rejects Uber Drivers "Robo-Firing" Charge But Tells Ola to Explain Algo-Deductions' (TC 2021), available at https://tcrn.ch/3dgSux3. For a detailed analysis, see Rosalind English, 'The Providers of 'Ride Hailing Apps' and their Drivers: Another Judgment from Amsterdam' (UK Human Rights Blog, 2021), available at https://bit.ly/2TrjLX3.

117. Regulation (EU) 2019/1150 of the European Parliament and of the Council of 20 June 2019 on promoting fairness and transparency for business users of online intermediation services.

118. Antonio Aloisi and others, 'A Manifesto to Reform the Gig Economy' Regulating for Globalization (2019) available at https://bit.ly/360J4CT. 
Social dialogue and collective bargaining are flexible solutions for promoting improved conditions for non-standard workers, as legislation and legal claims have been struggling to respond promptly and adequately to this rapidly evolving situation. ${ }^{19}$ The risk at present is that an inflexible interpretation of EU competition law could further exacerbate the situation of platform workers and many other casual workers, who are erroneously treated as 'undertakings' for the purposes of EU antitrust law and do not have the possibility of controlling their work processes, the price of their services and their conduct in the market. Many scholars have sought to interpret the scope of collective rights expansively to cover non-standard workers, thus curbing the unilateral enforcement of contractual and working conditions. ${ }^{120}$ The Commission launched a process at the EU level in 2020 to ensure that EU competition rules do not stand in the way of collective bargaining for those solo self-employed persons who need it. Despite the legal impediments, many experiments are emerging in several countries. ${ }^{121}$ It is therefore essential to ensure that those workers who are disenfranchised because of their employment status can effectively exercise the fundamental right to bargain collectively, recognised by international law instruments for 'workers' or 'everyone', without any distinction whatsoever. This can be achieved by updating the current legal framework at the EU level and, where appropriate, by adopting a modern interpretation of antitrust categories to allow for an improvement of the working conditions of larger segments of the labour force and help promote inclusive and sustainable growth. ${ }^{122}$

Platform workers have witnessed large-scale experimentation of outsourcing, algorithmic governance, customer reviews, gamification techniques, pay-per-drop models and false selfemployment schemes. The wildest inventions tested in this arena are symptoms of a much broader change sweeping across the labour market, posing significant challenges of varying degrees. Such a race to the bottom could increase inequalities and disrupt the welfare states. In the long-awaited 'second age' of platform work, an adaptive interpretation and a well-designed application of the current rules at the EU and national level are expected to strike a balance between safeguarding social rights, ensuring a level playing field for all operators and nurturing genuine innovation.

\section{Acknowledgements}

The article is based on a report for the European Centre of Expertise in the field of labour law, employment and labour market policies (ECE), commissioned for the 2020 ECE Annual Conference, 'Exploring ways to improve working conditions of platform workers: the role of EU labour law', held online on 25 January 2021.

119. European Social Partners, 'European Social Partners Framework Agreement on Digitalisation' (European Trade Union Confederation 2020), available at https:/www.etuc.org/en/document/eu-social-partners-agreement-digitalisation.

120. Nicola Countouris and Valerio De Stefano, 'New Trade Union Strategies for New Forms of Employment' (ETUC 2019), Brussels. See also OECD, 'Negotiating Our Way Up: Collective Bargaining in a Changing World of Work' (OECD Publishing 2019), https://doi.org/10.1787/1fd2da34-en.

121. Antonio Aloisi, 'Negotiating the Digital Transformation of Work: Non-Standard Workers' Voice, Collective Rights and Mobilisation Practices in the Platform Economy' (EUI MWP 2019).

122. European Commission, Guidelines on the Application of EU competition law to collective agreements regarding the working conditions of solo self-employed persons COM(2021) 8838 final. Despoina Georgiou, 'The European Commission's Draft Guidelines on the Application of EU Competition Law to Collective Agreements Regarding the Working Conditions of Solo Self-Employed Persons: Overview and Initial Assessment' (2021) available at https://bit.ly/3HR8yTj 
I am extremely grateful to Amina Majed Adwan, Gerrard Boot, Valerio De Stefano, Elena Gramano, Nastazja Potocka-Sionek, Silvia Rainone, the superb organising committee at the Goethe University of Frankfurt's Labour Law Chair, led by Professor Bernd Waas, and the conference participants for generating a great discussion and providing invaluable feedback on an earlier version of this article. The usual disclaimer applies.

\section{Declaration of conflicting interests}

The author declared no potential conflicts of interest with respect to the research, authorship, and/or publication of this article. 